\title{
Analisis Manajemen Risiko dalam Prosedur Pembiayaan Gadai Emas di BJB Syariah KCP Kuningan
}

\author{
Dewi Fatmasari, Anah Hasanah \\ Program Studi Perbankan Syariah, FSEI, IAIN Syekh Nurjati, Cirebon \\ email: dewifatmasari73@gmail.com
}

\begin{abstract}
Abstrak
Di dalam pembiayaan gadai emas Syariah (rahn) dilakukan oleh Rahin (pemilik barang) dan Al-Murtahin (penerima barang) dengan tujuan untuk memenuhi kebutuhannya bagi pemilik barang dengan menggadaikan barang tersebut sesuai prinsip Syariah. Pembiayaan gadai emas Syariah (rahn) memiliki prosedur yang dilalui hingga barang gadai tersebut kembali dimiliki oleh pemiliknya atau tidak, dan juga memiliki risiko-risiko yang melekat pada prosedur pembiayaan gadai emas. Sehingga diperlukan adanya manajemen risiko dalam prosedur pembiayaan gadai emas Syariah (rahn) supaya segala risiko yang ada dapat diminimalisir dan dapat diantisipasi dengan baik, demi terciptanya pembiayaan yang dapat memenuhi kebutuhan masyarakat dalam salah satu produk pembiayaan gadai emas di perbankan Syariah.

Penelitian ini termasuk penelitian analisis deskripstif. Metode analisis yang digunakan adalah metode kualitatif. Serta dalam menguji keabsahan data menggunakan teknik triangulasi. Teknik pengumpulan data dilakukan dengan cara wawancara, observasi, dan dokumentasi.

Hasil penelitian ini menunjukkan bahwa analisis manajemen risiko dalam prosedur pembiayaan gadai emas di BJB Syariah KCP Kuningan memiliki 10 prosedur yang dilalui dalam pembiayaan gadai emas Syariah dengan ketentuan tertentu di setiap prosedurnya yakni permohonan pembiayaan, penaksiran barang gadai, pelunasan penuh, pelunasan sebagian, perpanjangan, SP 1 s/d SP 2 atau setara 3, lelang, kuasa lelang, penjualan dan pelunasan atau penutupan pada sistem. Dan memiliki risiko yang ada pada setiap prosedur pembiayaan gadai emas Syariah (rahn) dilihat secara umum dan dilihat dari beberapa risiko yang dimiliki perbankan. Serta pada setiap prosedurnya memiliki manajemen risiko dalam satu kesatuan prosedur yang dilalui.
\end{abstract}

Kata Kunci: Manajemen Risiko, Prosedur Pembiayaan, Gadai Emas 


\begin{abstract}
Financing hearts of gold pawn in sharia (Rahn) conducted by Rahin (owner of goods) and Al-Murtahin (recipient Goods) with the aim to meet their needs review For the owner of the goods to pawn with Goods Under Sharia. Gold mortgage financing Sharia (Rahn) have procedures in recitals that passed the Back Up Goods pawn or not owned by their owners, and also had Risks Inherent on gold mortgage financing procedure. So, we need their hearts Risk Management Procedures gold pawn Financing Sharia (Rahn) Any order for Risks can be minimized and can be anticipated with good, in order to create Financing can be meet society hearts prayer One Needs Financing Products pawning gold in Islamic Banking.

Singer study included research deskripstif analysis. The analytical method used is a qualitative method. Test your hearts as well as the validity of the data using triangulation techniques. Data collection techniques with How to Interview, observation, and documentation.

Results The singer showed that the analysis of the Risk Management hearts procedure Financing pawning gold in BJB Syariah KCP Brass has 10 Procedures That traversed hearts Financing gold pawn sharia the terms Certain every procedure that request financing, valuation of goods mortgage, repayment sold, the repayment of, renewal, SP 1 s / d SP 2 OR 3 equivalents, auction, auction Counsel, Sales And repayment or in Closure System. And it has nothing to any Risks Funding Procedures gold pawn Sharia (Rahn) Viewed Operating Sales manager and Risks Seen From some owned banks. As well as on each procedures have hearts One Unit Risk Management Procedures The impassable.
\end{abstract}

Keywords: Risk Management, Finance Procedure, Gold Pawn. 


\section{Pendahuluan \\ Latar Belakang}

Lembaga keuangan adalah suatu lembaga yang memiliki fungsi untuk menghimpun dan menyalurkan dana ke masyarakat seperti perbankan. Sedangkan lembaga keuangan non bank adalah suatu lembaga yang hanya memiiki fungsi menghimpun dana dari masyarakat seperti lembaga pegadaian, asuransi dan lainnya. Pada dasarnya lembaga keuangan merupakan sebuah perantara dimana lembaga tersebut mempunyai fungsi dan peranan sebagai suatu lembaga yang menghimpun dana dari masyarakat yang kelebihan dana dan menyalurkan dana kepada masyarakat yang kekurangan atau membutuhkan dana agar terwujud masyarakat yang adil, makmur, dan sejahtera. ${ }^{1}$

Bank syariah adalah suatu lembaga keuagan yang usaha pokoknya memberikan kredit dan jasa-jasa lain dalam lalu lintas membayar serta peredaran uang yang menggunakan sistem dan operasinya berdasarkan prinsip-prinsip syariah. Artinya, operasi bank syariah tersebut didasarkan pada Al-Qur'an dan hadist. Sistem operasi bank syariah menggunakan sistem bagi hasil. ${ }^{2}$

Gagasan untuk memdirikan bank syariah di Indonesia sebenarnya sudah muncul sejak pertengahan tahun 1970-an. Gagasan tersebut dibicarakan pada seminar nasional hubungan Indonesia-Timur Tengah pada 1974 dan pada tahun 1976 dalam seminar

\footnotetext{
${ }^{1}$ Kasmir, Manajemen Perbankan. (Jakarta:Raja Grafindo Persada, 2003), 33

${ }^{2}$ Heri Sudarsono, Bank dan Lembaga Keuangan Syariah(Yogyakarta : Ekonisia 2003) 18
}

internasional yang diselenggarakan oleh lembaga studi ilmu kemasayarakatan (LSIK) dan Yayasan Bhineka Tunggal $\mathrm{Ika}^{3}$

Kehadiran bank syariah di tengah-tengah bank konvesional adalah untuk menawarkan sistem perbankan alternatif bagi umat Islam yang selama ini menikmati pelayanan perbankan dengan sistem bunga. Dalam perkembangan bank syariah yang sangat pesat, maka perbankan syariah mempunyai potensi dan peluang yang besar dalam peranannya sebagai sumber pembiayaan bagi hasil perekonomian. Dengan peluang dan potensi yang besar dalam perbankan syariah, memberikan inspirasi bagi bank konvesional untuk menerapkan dual system yaitu dengan sistem konvensional dan syariah. Bank-bank konvesional yang menerapkan dual system antara lain BNI Syariah, BRI Syariah, Permata Syariah, dan termasuk juga Bank Syariah Mandiri (BSM).

Terkait dengan sistem yang diterapkan oleh lembaga keuangan bank yaitu dual system dan double window, dimana sistem yang dapat diterapkan dalam satu lembaga perbankan dengan dua akad dan dua mekanisme. Seperti halnya perbankan konvensional dapat melakukan kegiatan transaksi kredit sesuai aturan bank konvensional sekaligus dapat melakukan kegiatan pembiayaan sesuai aturan bank syariah. Hal ini dilarang oleh MUI-DSN semenjak memasuki abad 21, karena dapat terjadi ketidakjelasan dan berbaurnya kegiatan yang diharamkan Islam yaitu yang mengharamkan riba.

${ }^{3}$ Heri Sudarsono, Bank dan Lembaga Keuangan Syariah..... 22 
BJB Syariah sudah memiliki banyak kantor cabang dan kantor cabang pembantu yang tersebar di Indonesia. Perkembangan BJB Syariah sangat pesat. Hal ini dapat dilihat dari jumlah asset yang dimiliki BJB Syariah sangat tinggi. Salah satu Kantor Cabang Pembantu BJB Syariah yaitu di daerah Kuningan Jawa Barat. Pada BJB Syariah KCP Kuningan menawarkan berbagai macam produk, yang tergolong produk dana, produk pembiayaan, produk jasa dan produk lainnya. Produk-produk tersebut tentunya ditawarkan untuk memenuhi kebutuhan masyarakat terutama masyarakat Kuningan. Masyarakat Kuningan mempunyai potensi yang sangat tinggi untuk menggunakan produk-produk di Bank Jabar Banten Syariah Kantor Cabang Pembantu Kuningan. Selain itu, letaknya strategis yang mempermudah masyarakat menjangkaunya. Itulah hal yang membuat masyarakat semakin menarik untuk menjadi nasabahnya. Satu diantara produk bank yang diminati di Bank Jabar Banten Syariah KCP Kuningan yaitu produk pembiayaan, salah satunya produk pembiayaan gadai emas (Ar-rahn).

Dalam UU No. 40 Tahun 2007 tentang Perseroan Terbatas, diatur bahwa suatu saham perseroan dapat dijadikan jaminan dengan gadai atau jaminan fidusia. Namun demikian, Bank Indonesia hanya mengatur bahwa untuk suatu saham dapat dilakukan pengikatan berdasarkan gadai. Oleh karena itu, dalam praktik perbankan, suatu saham tidak diikat secara jaminan, tetapi diikat dengan gadai. ${ }^{4}$ Menurut kitab Undang-Undang Hukum

\footnotetext{
${ }^{4}$ Tri Widiyono,Agunan Kredit dalam Financial Engineering (Bogor:Ghalia Indonesia, 2009)241
}

Perdata Pasal 1150, gadai adalah satu hak yang diperoleh seorang yang mempunyai piutang atas suatu barang bergerak. Tersebut diserahkan kepada orang atas berpiutang oleh seorang yang mempunyai hutang atau oleh orang lain atas nama orang yang mempunyai hutang seorang yang berhutang tersebut.

Gadai dalam fiqh disebut rahn yang menurut bahasa adalah nama barang yang dijadikan sebagai jaminan kepercayaan. Barang yang digadaikan dapat berupa kendaraan, emas atau barang bergerak lainnya. ${ }^{5}$ Keberadaan gadai telah ada pada masa yang sangat lama dalam dunia Islam, dengan diturunkannya wahyu kepada Nabi Muhammad SAW, sebagaimana firman Allah SWT dalam Al-Qur'an dan AlHadits.

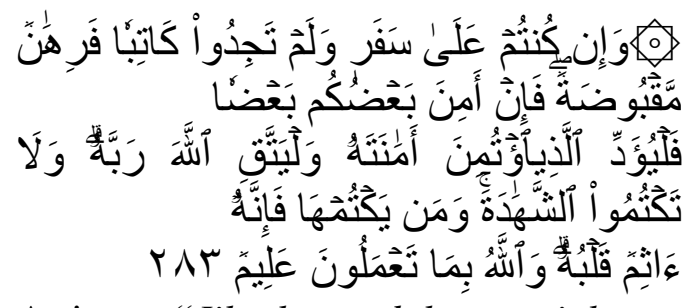

Artinya: "Jika kamu dalam perjalanan (dan bermu'amalah tidak secara tunai) sedang kamu tidak memperoleh seorang penulis, maka hendaklah ada barang tanggungan yang dipegang ${ }^{6}$ (oleh yang berpiutang). Akan tetapi jika sebagian kamu mempercayai sebagian yang lain, maka hendaklah yang dipercayai itu menunaikan amanatnya (hutangnya) dan hendaklah ia bertakwa kepada Allah Tuhannya; dan janganlah kamu (para saksi) menyembunyikan persaksian. Dan

${ }^{5}$ Heri Sudarsono, Bank dan Lembaga Keuangan Syariah....,, 141

${ }^{6}$ Barang tanggungan (borg) itu diadakan bila satu sama lain tidak percaya mempercayai. 
barangsiapa

menyembunyikannya,

yang

maka

sesungguhnya ia adalah orang yang

berdosa hatinya; dan Allah Maha

mengetahui apa yang kamu kerjakan." (Q.S.Al-Baqarah:283) ${ }^{7}$

Kegiatan gadai pada penafsiran QS.Al-Baqarah:283 bahwa adanya suatu kegiatan gadai tidak terkecuali dapat dilaksanakan bagi siapa pun yang bertempat tinggal maupun yang sedang dalam perjalanan selama keduanya memenuhi syarat sahnya dan rukun dalam gadai. Salah satu kegiatan gadai yang dilakukan di suatu tempat tinggal yaitu dapat dilakukan di lembaga atau tempat yang menawarkan kegiatan pembiayaan gadai, satu diantaranya yang berada di BJB Syariah KCP Kuningan. Di BJB Syariah KCP Kuningan memberikan fasilitas untuk produk pembiayaan gadai berupa emas. Artinya, dalam operasinya barang yang digadaikan yaitu berupa emas. Pada pelaksanaan gadai emas di BJB Syariah Kantor Cabang Pembantu Kuningan ini menggunakan prinsip qard, prinsip rahndan prinsip ijarah. Disamping itu, ada ketentuan-ketentuan yang harus dipenuhi oleh nasabah dalam pengajuan pembiayaan gadai emas. Terutama terkait dalam pembiayaan gadai emas ini memiliki prosedur tersendiri dalam pelaksanaannya.

Prosedur merupakan urutan kegiatan atas suatu transaksi yang dilakukan secara berulang-ulang. ${ }^{8}$

\section{${ }^{7}$ Al-Qur'anul}

KarimDepartemen Agama Republik Indonesia, Al-Qur,an dan Terjemahannya juz 1- juz 30 (Jakarta: Yayasan Penerjemah Depag, 2003) 60 ${ }^{8}$ Nadhifatul Kholifah,

Topowijoyo dan Devi Farah Azizah. Analisis Sistem Dan Prosedur Gadai Emas Syariah (Studi Pada PT. Bank
Prosedur pembiayaan gadai emas syariah ini memiliki kemungkinan risiko yang bisa saja terjadi baik sengaja atau tidak sengaja, bisa saja risiko timbul dari pihak internal (bank) sebagai pengelola dan mungkin saja risiko timbul dari pihak eksternal (nasabah atau pihak lainnya yang berkaitan). Terkait emas merupakan barang yang berharga dan memiliki nilai jual dan nilai beli sampai kapanpun, dan peraturan tentang adanya manajemen risiko terhadap pembiayaan gadai emas, dimana manajemen risiko merupakan bagian dari kegiatan operasional suatu perusahaan. Dan dalam situasi perkembangannya yang pesat pada lingkungan eksternal dan internal perbankan yang diikuti dengan semakin kompleksnya risiko kegiatan usaha perbankan sehingga meningkatkan kebutuhan praktik tata kelola bank yang sehat (good corporate governance) dan penerapan manajemen risiko. ${ }^{9}$ Terutama perkembangan produk qardh beragun emas yang semakin pesat yang dapat meningkatkan risiko bagi Perbankan Syariah. $^{10}$ Karena risiko merupakan

Mega Syariah Dan PT. Bank BNI Syariah Kantor Cabang Malang), 3 April 2013. 3,http://www.ejurnal.com/2014/05/ana lisis-sistem-dan-prosedur-gadai-

emas.html. Diakses 13 November 2015 lihat juga (Mulyadi, 2009: 5)

9 Veithzal Rivai, Sofyan Basir, Sarwono Sudarto, dan Ariflandy Permata Veithzal. Commercial Bank Management Manajemen Perbankan dari Teori ke Praktek (Jakarta: PT Raja Grafindo Persada, 2012) 549

${ }^{10}$ Surat edaran perihal produk qardh beragun emas bagi bank Syariah dan unit usaha bank Syariah. 
penyebaran hasil aktual dari hasil yang diharapkan (risk is the dispersion of actual from expected results) ${ }^{11}$. Penyebaran hasil aktual ini, bisa berupa segala kemungkinan yang belum diketahui. Bisa saja kemungkinan itu sesuatu yang diharapkan dan sesuatu yang tidak diharapkan. Risiko dalam gadai emas itu sendiri merupakan suatu keadaan yang melatar belakangi terjadinya kerugian dalam pembiayaan gadai emas diantaranya bisa bersumber dari suatu kesalahan yang disengaja atau tidak sengaja dari pihak bank atau nasabah maupun pihak lain yang berkaitan dalam suatu kegiatan pembiayaan di Perbankan Syariah.

\section{Metode Penelitian}

Metode penelitian yang dipilih menggunakan metode kualitatif, dimana metode yang memaparkan penelitian dengan berdasarkan datadata yang akurat tersusun secara sistematis. Metode analisis yang digunakan adalah analisis deskriptif yaitu menggambarkan atau menguraikan sesuatu hal menurut apa adanya. ${ }^{12}$ Sedangkan jenis penelitian yang penulis lakukan dalam peneltian ini berupa penelitian studi pustaka, yaitu mengkaji sumber referensi dari buku-buku atau sumber bacaan lainnya yang mengkaji tentang analisis manajemen risiko di dalam prosedur pembiayaan gadai emas.

No.14/7/DPbS. Jakarta, 29 Februari 2012

11 Herman Darmawi.

Manajemen Risiko......20

Lawrens, Kamus Burhani MS,Hasb

Populer(Jombang:Lintas Media,t.t)88

\section{Pembahasan}

\section{Prosedur pembiayaan gadai emas di BJB Syariah KCP Kuningan}

Prosedur

merupakan

serangkaian langkah-langkah yang dilalui secara berulang-ulang dalam suatu kegiatan tertentu. Prosedur adalah jalur penyelesaian (masalah); cara bekerja; cara menyertakan (pendapat/usulan). ${ }^{13}$ Salah satu prosedur yang ada pada pembiayaan yang dilakukan oleh suatu lembaga keuangan.

Menurut Undang-Undang Perbankan No. 10 Tahun 1998, pembiayaan adalah penyediaan uang atau tagihan yang dapat dipersamakan dengan itu, berdasarkan persetujuan atau kesepakatan antara bank dan pihak lain yang dibiayai untuk mengembalikan uang atau tagihan tersebut setelah jangka waktu tertentu dengan imbalan atau bagi hasil. ${ }^{14}$

Untuk pembiayaan gadai emas dalam Islam disebut rahn, gadai emas atau rahn disebut juga ar-rahn (mortgage) adalah menahan salah satu harta miliki si peminjam sebagai jaminan atas pinjaman yang diterimanya. Barang yang ditahan tersebut memiliki nilai ekonomis. Dengan demikian, pihak yang menahan memperoleh jaminan untuk dapat mengambil kembali seluruh atau sebagian piutangnya. Secara sederhana dapat dijelaskan bahwa rahn adalah semacam jaminan utang atau gadai. ${ }^{15}$

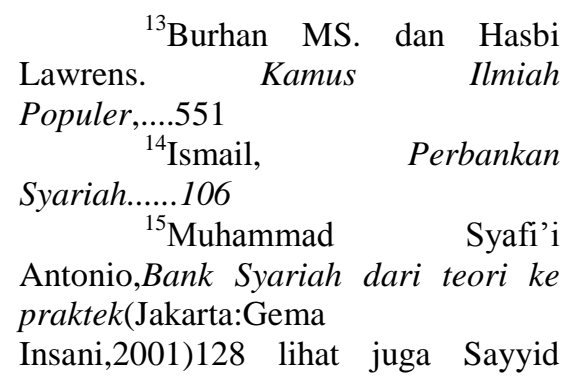


Ciri utama dalam pembiayaan gadai emas adalah emas tersebut menjadi objek yang digadaikan atas pencairan pembiayaan yang dapat diterima oleh nasabah sesuai aturan yang berlaku. Jadi, terkabulnya atau tercapainya pembiayaan yang diajukan nasabah atas permohonan pembiayaan gadai emas tergantung dengan hasil taksiran atau persentase yang diperoleh dari emas nasabah tersebut.

\section{Prosedur Permohonan Pembiayaan Gadai Emas di BJB Syariah KCP Kuningan}

Prosedur yang ada dalam permohonan pembiayaan gadai emas di BJB Syariah KCP Kuningan, pada langkah pertama untuk memastikan bagaimana persyaratan yang harus dipenuhi oleh nasabah yang akan mengajukan pembiayaan gadai. Hal ini, sebagaimana yang diungkapkan oleh pegawai bank yang menangani pembiayaan gadai emas dan persyaratan yang tertera pada brosur produk gadai emas tersebut. Persyaratan dalam pengajuan permohonan pembiayaan gadai emas di BJB Syariah KCP Kuningan, yaitu: ${ }^{16}$ Perorangan (WNI) atau badan usaha Indonesia, cakap hukum, mempunyai kartu identitas (KTP/SIM/Pasport) yang masih berlaku dengan menunjukan aslinya

Sabiq, Fiqhus Sunnah (Beirut: DarulKitab al-Arabi,1987), cetakan ke-8, vol.111, hlm.169; Abdurrahman alJaziry,al-Fiqh ala Madzahib alArba'ah( Beirut:DarulQalam,t.t.),vol.11, hlm. 305.

${ }^{16}$ Brosur produk gadai emas

"Mitra Emas Ib Maslahah" BJB Syariah KCP Kuningan. Dan file data presentasi dibiro gadai BJB Syariah a. Membuka/mempunyai buku tabungan atau rekening di BJB Syariah

b. Menyampaikan NPWP untuk plafon tertentu sesuai ketentuan yang berlaku

c. Mengisi formulir permohonan Mitra Emas Ib Maslahah

d. Menandatangani akad dan dokumen pendukung lainnya

e. Menyerahkan agunan emas (emas perhiasan, emas batangan atau koin emas) dengan kadar minimal 16 karat atau $67 \%$.

Dalam formulir permohonan pembiayaan gadai emas, nasabah harus memahami bagaimana isi yang ada didalamnya dengan dibantu dijelaskan oleh pegawai bank yang menangani pembiayaan gadai emas tersebut, supaya tujuan diantara kedua belah pihak dapat terpenuhi sebagaimana kewajiban dan hak bagi keduanya yaitu antara nasabah yang mengajukan pembiayaan gadai emas dan pihak bank. Disamping nasabah telah memenuhi syarat yang ada dalam pengajuan pembiayaan gadai emas, selanjutnya ke tahap prosedur penaksiran pada barang yang akan digadaikan oleh nasabah untuk melengkapi data formulir didalamnya dan sebagai pertimbangan diterima atau tidaknya permohonan pembiayaan gadai emas atas hasil taksiran barang gadai yang dibawa oleh nasabah tersebut. 


\section{Prosedur Penaksiran Barang yang Digadaikan dalam Pembiayaan Gadai Emas di BJB Syariah KCP Kuningan}

Proses penaksiran tersebut di antaranya sebagai berikut: ${ }^{17}$

a. Petugas gadai melihat Standar Harga Emas yang ditetapkan oleh Divisi Dana dan Jasa BJB Syariah Pusat. Standar Harga Emas tersebut selalu berubah-ubah sesuai perkembangan harga pasar emas yang berlaku.

b. Petugas gadai menentukan karatase dari barang jaminan emas tersebut dengan menggunakan metode sebagai berikut: ${ }^{18}$

1) Metode jarum uji emas

Pengujian dengan
metode ini dilakukan dengan
cara membandingkan kecepatan
pelarutan goresan emas yang
diuji terhadap kecepatan
pelarutan goresan dari jarum uji
yang sudah diketahui
karatasenya. Alat-alat yang
digunakan dalam metode ini di
antaranya yaitu jarum uji emas,
batu uji, larutan uji emas yaitu
asam nitrat dan asam chloride,
botol air uji emas yang
berwarna oranye gelap, pipet
tetes dan issue.

2) Metode berat jenis

Metode ini menerapkan hukum Archimedes yaitu mengukur berat jenis barang

17 Wawancara dengan Pak Dimas Priangga Nugraha, selaku Pegawai administrasi bagian penilaian jaminan sekaligus sebagai layanan analisis emas di BJB Syariah KCP Kuningan. 10 Maret 2016

18 Hasil observasi dan dokumentasi di Kantor BJB Syariah KCP Kuningan. Selama PKL di bulan Oktober 2015 dan observasi dan wawancara 10 Maret 2016 emas dan membandingkannya dengan berat jenis standar emas. Alat-alat yang digunakan dalam metode ini antara lain: Timbangan (digital atau manual), Gelas ukur atau bejana tempat air, Air murni, Tempat timbangan emas atau tali pengikat, Memeriksa keaslian dari barang jaminan emas tersebut. dengan cara sebagai berikut:

a) Menggosokkan emas dan barang lain sebagai pembanding (perak atau besi) pada sebuah batu (batu uji) kemudian diberikan cairan kimia khusus. Selanjutnya lihat hasil dari goresan tersebut, jika goresannya hilang maka emas tersebut bukanlah emas asli, sedangkan jika goresan emas tersebut masih ada, maka emas tersebut asli.

b) Menjatuhkan emas tersebut, jika bunyi atau suara yang dihasilkan dari emas tersebut terdengar ringan, maka emas tersebut bukanlah emas asli. Begitupun sebaliknya, jika bunyi atau suaranya terdengar berat, maka emas tersebut asli.

Petugas gadai menentukan nilai taksiran dan pembiayaan sesuai dengan ketetapan yang telah ditentukan oleh pihak Bank BJB Syariah. Dengan rumus sebagai berikut: ${ }^{19}$

19 Wawancara dengan Pak Dimas Priangga Nugraha, selaku Pegawai administrasi bagian penilaian jaminan sekaligus sebagai layanan analisis emas 
Rumus cara menentukan nilai taksiran untuk emas perhiasan

$\frac{\text { Total Karatase }(24)}{\text { Total Karatase }(24)} \times$ Taksiran x Berat Emas (Gram) x 85\%

Rumus cara menentukan nilai taksiran untuk logam mulia (LM)

$\frac{\text { Total Karatase (24) }}{\text { Total Karatase (24) }} \times$ Taksiran x Berat Emas (Gram) x 90\%

Rumus cara menentukan ujrah

Ujroh $=$ berat emas $\mathrm{x}$ ujroh $\mathrm{x}$ jangka waktu pembiayaan

Biaya Administrasi: biaya materai 2 buah.

Biaya Pemeliharaan: ${ }^{20}$

\begin{tabular}{cc}
\hline Karatase & Keterangan \\
\hline $\mathbf{1 6}$ & Rp. 4.250/gram \\
$\mathbf{1 7}$ & Rp. 4.250/gram \\
$\mathbf{1 8}$ & Rp. 4.350/gram \\
$\mathbf{1 9}$ & Rp. 4.350/gram \\
$\mathbf{2 0}$ & Rp. 4.400/gram \\
$\mathbf{2 1}$ & Rp. 4.400/gram \\
$\mathbf{2 2}$ & Rp. 4.450/gram \\
$\mathbf{2 3}$ & Rp. 4.450/gram \\
$\mathbf{2 4}$ & Rp. 4.550/gram \\
\hline
\end{tabular}

c) Jika hasil taksiran pada barang gadai telah didapatkan, untuk menentukan keputusan diterima atau tidaknya permohonan gadai atas barang tersebut dibutuhkan adanya konfirmasi dengan komite para pimpinan yang berada di kantor.

\section{Risiko-risiko dalam prosedur pembiayaan gadai emas di BJB Syariah}

Risiko adalah suatu perubahan atau perbedaan dari hasil yang tidak diharapkan. $^{21}$ Penyebab risiko nampak ketika sudah terjadinya suatu kerugian yang tidak diharapkan. Dua faktor yang menimbulkan kerugian adalah bencana (perils) yaitu penyebab penyimpangan peristiwa sesungguhnya dari yang diharapkan dan bahaya (hazards) yaitu keadaan yang melatarbelakangi terjadinya kerugian oleh bencana tertentu. $^{22}$ Risiko dalam gadai emas itu sendiri merupakan suatu keadaan yang melatarbelakangi terjadinya kerugian dalam pembiayaan gadai emas diantaranya bisa bersumber dari suatu kesalahan yang disengaja atau tidak sengaja dari pihak bank atau nasabah maupun pihak lain yang berkaitan dalam suatu kegiatan pembiayaan di Perbankan Syariah.

Manajemen risiko dalam prosedur pembiayaan gadai emas di BJB Syariah KCP Kuningan, mengulas bagaimana risiko yang tidak diharapkan dalam pembiayaan gadai emas untuk memanajemen risiko tersebut. Risiko yang ada dalam setiap prosedur pembiayaan gadai emas di BJB Syariah KCP Kuningan, merupakan salah satu kegiatan mengidentifikasi risiko yang ada dalam setiap prosedur pembiayaan gadai emas, yang kemudian akan dibahas lebih lanjut untuk mengatasi barbagai risiko-risiko tersebut pada pembahasan

21 Tariqullah Khan dan Habib Ahmad, Manajemen Risiko Lembaga Keuangan Syariah (Jakarta: Bumi Aksara, 2008) 9

${ }^{22}$ Kasidi. Risiko.......5-6
Manajemen

di BJB Syariah KCP Kuningan. 10 Maret 2016

${ }^{20}$ Berlaku per tanggal 10 Maret 2016 
selanjutnya pada setiap kemungkinan yang bisa terjadi.

Untuk dapat mengetahui bagaimana risiko-risiko yang ada dalam setiap prosedur pembiayaan gadai emas di BJB Syariah KCP Kuningan, penulis memaparkannya sesuai hasil data yang ada dengan menyertakan risiko yang ada pada setiap prosedur pembiayaan gadai emas. Jenis-jenis risiko secara umum diantaranya yaitu: ${ }^{23}$

1. Risiko spekulatif (speculative risk), adalah risiko yang mengandung dua kemungkinan, yaitu kemungkinan menguntungkan atau kemungkinan merugikan.

2. Risiko murni (pure risk), adalah risiko yang mengandung satu kemungkinan, yaitu kemungkinan rugi saja.

3. Risiko dinamis, adalah risiko yang timbul dari adanya perkembangan dan kemajuan (dinamika) masyarakat di bidang ekonomi, ilmu dan teknologi, seperti risiko keuangan. Risiko statis seperti halnya risiko hari tua, risiko kematian dan sebagainya.

4. Risiko khusus, ialah risiko yang bersumber pada peristiwa yang mandiri dari umumnya mudah diketahui penyebabnya, seperti kecelakaan teknis.

5. Risiko fundamental, ialah risiko yang tidak dapat dilimpahkan kepada seseorang tetapi banyak orang, seperti bencana alam.

Risiko operasional dalam prosedur pembiayaan gadai emas di BJB Syariah KCP Kuningan, yaitu:

\begin{tabular}{llr}
\multicolumn{2}{c}{${ }^{23}$ Kasidi. } & \multicolumn{2}{r}{ Manajemen } \\
Risiko.......5. lihat juga & Soeisno \\
Djojosoedarso, & Prinsip- & Prinsip \\
Manajemen & Risiko & Dan \\
Asuransi............ 3 & &
\end{tabular}

a. Dalam prosedur permohonan pembiayaan gadai emas di BJB Syariah KCP Kuningan, menghadapi risiko ketika pihak bank tidak cermat dalam kegiatan identifikasi atau untuk mengidentifikasi atas verifikasi nasabah yang kurang tepat, akibatnya ketika masalah yang berkaitan dengan keberadaan barang gadai tersebut masih belum sah kepemilikannya. $^{24}$

b. Dalam prosedur penaksiran barang gadai dalam prosedur pembiayaan gadai emas di BJB Syariah KCP Kuningan, adanya kesalahan dalam taksiran yang tidak sesuai dengan kondisi emas. ${ }^{25}$

c. Untuk risiko yang ada dalam prosedur SP 1 s/d SP 2 atau setara 3 pada pembiayaan gadai emas, yaitu: "Dalam hal maintenance sulit menghubungi nasabah untuk memberitahukan kesepakatan atau ujroh yang sudah jatuh tempo". ${ }^{26}$ Hal ini, termasuk masalah menjaga komunikasi itu sendiri antara nasabah dan bank yang bersangkutan.

${ }^{24}$ Wawancara dengan ibu Deva Yuliani selaku Manajer Operasional dan Pak Dimas Priangga Nugraha selaku Pegawai administrasi bagian penilaian jaminan sekaligus sebagai layanan analisis emas di BJB Syariah KCP Kuningan. 10 Maret 2016

${ }^{25}$ Wawancara dengan ibu Deva Yuliani selaku Manajer Operasional dan Pak Dimas Priangga Nugraha selaku Pegawai administrasi bagian penilaian jaminan sekaligus sebagai layanan analisis emas di BJB Syariah KCP Kuningan. 10 Maret 2016

${ }^{26}$ Hasil wawancara dengan Pak Dimas Priangga Nugraha, Karyawan Bank BJB Syariah tanggal 16 Oktober 2015 
d. Dalam prosedur penjualan barang lelang yang hanya dilakukan oleh pihak bank, ketika adanya kerusakan/perbedaan data karena kecurangan maka akan terjadi tertundanya kegiatan penjulan sampai batas waktu yang dapat ditoleransi, hingga kegagalan dilakukannya penjualan barang gadai tersebut yang akan menyebabkan terjadinya kerugian bank. $^{27}$

e. Risiko pada barang jaminan ${ }^{28}$ yaitu kemungkinan yang bisa saja terjadi pada barang objek yang digadaikan oleh nasabah kepada bank untuk dijaga atau dipelihara tersebut rusak atau hilang dicuri. Hal ini jika terjadi, dapat mengakibatkan hilangnya kepercayaan nasabah kepada bank hingga kepada menurunya keuntungan bank dari produk pembiayaan gadai.

\section{Manajemen Risiko dalam Prosedur Pembiayaan Gadai Emas di BJB Syariah KCP Kuningan.}

Manajemen merupakan segala proses kegiatan dalam mencapai tujuan melalui penentuan terlebih dahulu, yang meliputi perencanaan, pelaksanaan/ pengorganisasian, pengawasan dan pengendalian dengan memperdayakan sumber daya yang dimilki untuk dapat berperan lebih efektif (tepat, manjur, mujarab, tepat

${ }^{27}$ Isi SOP pedoman pembiayaan Gadai Emas Syariah di BJB Syariah KCP Kuningan

${ }^{28}$ Anita Ristqi P, Aspek Risiko Produk Gadai Emas Pada Pegadaian Syariah Cabang

Cinere, ANITA RISTOL P-FSH-

1.pdf. diakses 10 November 2015 guna, berhasil) ${ }^{29}$ dan efisien (rapi, cermat, paling sesuai dan tepat, hemat waktu (biaya, tenaga) ${ }^{30}$. Risiko ialah menyimpangnya sesuatu dari apa yang diharapkan dan tidak diharapkan dalam suatu tujuan yang hendak dicapai dalam proses atau perjalanan sesudah dan sebelum bahkan sedang berjalannya suatu kegiatan tersebut dalam mencapai tujuan. ${ }^{31}$

Manajemen risiko adalah suatu usaha secara rasional untuk menghindari atau mengurangi kerugian atau cidera. $^{32}$ Manajemen risiko merupakan manajemen fungsional didalam perusahaan, maka obyektif utama manajemen risiko harus menyokong obyektif perusahaan yang bersangkutan. $^{33}$

Manajemen risiko dalam prosedur pembiayaan gadai emas di BJB Syariah KCP Kuningan, yang keberadaanya tidak terlepas dari semua objek manajemen risiko suatu perusahaan yaitu untuk kelangsungan hidup atau kelanggengannya perkembangan bank tersebut atau pihak yang berkepentingan (stakeholders) sesuai salah satu misi bank BJB Syariah.

Visi bank BJB Syariah KCP Kuningan yaitu menjadi 5 Bank Umum Syariah terbesar, sehat dan berkinerja baik di Indonesia, serta merumuskan

${ }^{29}$ Burhan MS. dan Hasbi Lawrens. Kamus Ilmiah Populer, (Jombang: Lintas Media,t.t)107

${ }^{30}$ Burhan MS. dan Hasbi Lawrens. Kamus Ilmiah Populer,....107

${ }^{31}$ Kasidi. Manajemen Risiko (Bogor: Ghalia Indonesia, 2010) 4

${ }^{32}$ Kasidi. Manajemen

Risiko............ 4

Darmawi. Manajemen Risiko ( Jakarta: PT Bumi Aksara, 2008) 14 
tanggung jawab sosial perusahaan terhadap perusahaan dan masyarakat yang sesuai dengan misi bank BJB Syariah KCP Kuningan diantaranya yaitu mendorong pertumbuhan perekonomian daerah melalui peningkatan Usaha Mikro, Kecil, dan Menengah (UMKM) dan memberikan nilai tambah bagi stakeholders. Sebagaimana kaitannya pembiayaan gadai emas dengan visi dan misi BJB Syariah sesuai ungkapan pegawai bank BJB Syariah KCP Kuningan yaitu "meningkatkan taraf hidup steakholder-mikro" 34 .

Untuk dapat menerapkan manajemen risiko secara efektif berpotensi menjadi basis penyusunan strategi dan bermanfaat untuk: ${ }^{35}$

1. Mengelola perubahan

2. Melibatkan semua pegawai pada semua tingkatan dalam organisasi untuk memenuhi tujuan usaha

3. Memberikan gambaran kepada pengelola Bank mengenai kemungkinan kerugian Bank di masa datang

4. Meningkatkan metode dan proses pengambilan keputusan yang sistematis yang didasarkan atas ketersediaan informasi

5. Memiliki kemampuan menghimpun dana murah

6. Meningkatkan Credit rating

7. Meningkatkan nilai saham (shareholder value) dalam jangka

34 Wawancara dengan Pak Dimas Priangga Nugraha, selaku Pegawai administrasi bagian penilaian jaminan sekaligus sebagai layanan analisis emas di BJB Syariah KCP Kuningan. 13 November 2015

${ }^{35}$ Robert Tampubolon, Manajemen Risiko Pendekatan Kualitatif untuk Bank Komersial (Jakarta: PT Elex Media Komputindo, 2004)11 panjang (bagi bank yang telah go public)

8. Pada akhirnya untuk menurunkan biaya modal

9. Untuk mengetahui terjadinya suatu perubahan pada variabel-variabel yang berpengaruh terhadap terjadinya peril dan upaya penanggulangannya yang meliputi: biaya, program keselamatan, pencegahan kerugian dan sebagainya. Maka hal ini perlu adanya tindakan review secara berkala supaya tindakan manajer risiko tetap berlaku secara efektif sepanjang waktu. ${ }^{36}$

Dalam dunia perbankan dikenal pula sejumlah jenis risiko. Di antara jenis risiko yang menjadi pusat perhatian bank adalah risiko pasar, risiko kredit, dan risiko operasional. ${ }^{37}$ Manajemen risiko (risk management) merupakan proses yang berkelanjutan dalam upaya menekan pengaruh buruk risiko tersebut. ${ }^{38}$ Bank Indonesia mendefinisikan manajemen risiko sebagai serangkaian prosedur dan metodologi yang digunakan untuk mengidentifikasi, mengukur, memantau, dan mengendalikan risiko yang timbul dari kegiatan usaha Bank. $^{39}$ Proses manajemen risiko

\section{${ }^{36}$ Soeisno Djojosoedarso,} Prinsip- Prinsip Manajemen Risiko Dan Asuransi............. 17

${ }^{37}$ Masyhud Ali, Manajemen Risiko Strategi Perbankan dan Dunia Usaha Menghadapi Tantangan Globalisasi Bisnis (Jakarta: PT Raja Grafika Persada, 2006) 311

${ }^{38}$ Masyhud Ali, Manajemen Risiko Strategi Perbankan dan Dunia Usaha Menghadapi Tantangan Globalisasi Bisnis..................313

${ }^{39}$ Yayat M. Herujito, DasarDasar Manajemen....33 
dalam prosedur pembiayaan gadai emas di BJB Syariah KCP Kuningan:

1. Identifikasi risiko dalam prosedur pembiayaan gadai emas di BJB Syariah KCP Kuningan.

Identifikasi risiko pada dasarnya adalah suatu kegiatan untuk mengumpulkan semua informasi yang berkaitan dengan kegiatan usaha. ${ }^{40}$ Pengidentifikasian risiko itu merupakan proses penganalisisan untuk menemukan secara sistematis dan secara berkesinambungan risiko (kerugian yang potensial) yang menantang perusahaan. ${ }^{41}$ Kegiatan identifikasi merupakan kegiatan pengenalan pada sesuatu hal yang memiliki risiko terhadap tujuan yang sudah disepakati untuk selanjutnya akan ditindaklanjuti. Mengingat beberapa proses pengidentifikasian dan penilaian risiko yang umumnya dilakukan Bank, yaitu dengan melakukan halhal seperti berikut: ${ }^{42}$

\section{a) Self-Assessment}

Tindakan penilaian terhadap kegiatan usaha sendiri yang memiliki risiko dengan menilai risiko kredit maupun risiko operasional yang dimiliki bank. Teknik yang sering digunakan pada penilaian sendiri ini dengan menggunakan check-list karena sederhana dan efektif.

b) Risk Mapping

Membuat peta konsep dari setiap proses risiko-risiko yang ada.

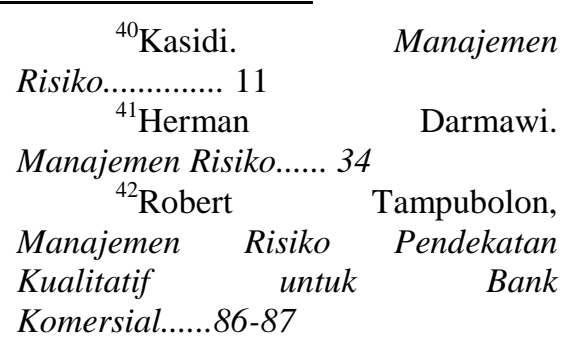

c) Key Risk Indicators

Indikator risko yang disajikan dalam data statistik atau metric yang menggambarkan posisi risiko sebuah bank.

d) Scorecards

Membuat hasil penilaian dalam bentuk angka untuk menggambarkan berbagai rangking dari risiko.

e) Threshold/limits

Batasan yang menggambarkan peringatan dini pada manajemen tentang kemungkinan adanya masalah yang memerlukan tindakan perbaikan sesegera mungkin.

2. Pengukuran risiko dalam prosedur pembiayaan gadai emas di BJB Syariah KCP Kuningan

Pengukuran pada setiap prosedur pembiayaan gadai emas di BJB Syariah KCP Kuningan, suatu kegiatan yang menggambarkan seberapa besar risiko yang ada dalam prosedur gadai dapat mempengaruhi kegiatan dalam setiap prosedur gadai sendiri terhadap kegiatan gadai pada masa sekarang dan selanjutnya.

a. Pengukuran risiko dalam prosedur permohonan gadai melihat bagaimana hasil analisis nasabah dan pemenuhan persyaratan yang ada dalam gadai. Jika hasil analisis nasabah terdapat suatu pernyataan adanya faktor yang meragukan untuk dapat dipercaya nasabah tersebut oleh bank, maka akan dipertimbangkan lagi dengan hasil penyelidikan pada persyaratan yang di bawa nasabah dalam pengajuan pembiayaan gadai emas. Dalam persyaratan nasabah yang 
mengajukan pembiayaan gadai emas, ketika ada beberapa syarat yang dianggap begitu penting tetap harus memenuhi persyaratan tersebut dan nasabah tidak memenuhi persyaratan tersebut maka pemberian pembiayaan gadai tidak dapat dikabulkan/tidak dapat dilanjutkan/ pengajuan pembiayaan akan gagal. Berikut beberapa persyaratan yang penting dan harus dipenuhi oleh nasabah dalam pengajuan pembiayaan gadai, yaitu: membawa salah satu data surat identitas diri (KTP/Pasfort/SIM), membawa barang (emas perhiasan/logam mulia) yang akan digadaikan minimal 16 karat, membawa buku tabungan bank BJB Syariah. Persyaratan tersebut seperti foto kopi identitas nasabah yang mengajukan pembiayaan gadai, dapat dibantu oleh bank secara teknis untuk memfoto kopi identitas tersebut di kantor. Begitu pula jika hasil analisis nasabah tetap meragukan tetapi jika persyaratan nasabah yang mengajukan pembiayaan gadai telah terpenuhi maka proses pemberian pemberian akan ditindaklanjuti sebagaimana akan melewati prosedur penaksiran pada barang yang akan digadaikan oleh nasabah yang bersangkutan.

b. Pengukuran risiko dalam prosedur penaksiran barang yang digadaikan dalam pembiayaan gadai emas di BJB Syariah KCP Kuningan. Pengukuran risiko pada penaksiran barang gadai cukup bagaimana hasil barang tersebut setelah melalui beberapa prosedur dalam penaksiran yang berlaku. Jika hasil taksiran barang gadai memenuhi ketentuan taksiran yang berlaku, maka akan dapat mengabulkan permohonan pembiayaan gadai yang diajukan nasabah dan bank dapat memberikan pencairan dana atas hasil taksiran barang gadai yang sesuai ketentuan bank yang berlaku. Tetapi, jika hasil taksiran tidak memenuhi ketentuan yang berlaku maka bank tidak dapat mengabulkan permohonan pembiayaan gadai yang diajukan nasabah tersebut. Sehingga jika terjadi penolakan pada pengajuan pembiayaan gadai atas hasil taksiran yang didapat, proses prosedur pembiayaan gadai tidak akan berlanjut pada prosedur pelunasan. Karena keberlanjutan prosedur pembiayaan gadai hanya akan berlanjut ketika pengajuan berhasil dikabulkan pada setiap prosedurnya.

c. Pengkuran risiko dalam prosedur pelunasan penuh pembiayaan gadai emasdi BJB Syariah KCP Kuningan. Pengukuran risiko pada saat pelunasan penuh yang di anggap tidak terlalu berat yaitu ketika aset bank berkurang, karena hal ini termasuk konsekuensi dari adanya pengambilan aset yang tadinya di simpan di bank akan di ambil oleh pemiliknya dengan adanya pelunasan. Pengukuran risiko yang dianggap tidak bisa melanjutkan kegiatan pelunasan penuh, yaitu saat nasabah tidak membawa persyaratan yang lengkap ketika akan mengajukan 
pelunasan penuh. Tetapi ketika persyaratan yang tidak terpenuhi dapat digantikan dengan yang lain masih dapat dilanjutkan pengajuan tersebut. Berbeda pada saat persyaratan yang wajib ada itu harus ada maka pengajuan pelunasan penuh pada pembiayaan gadai tidak bisa dilanjutkan.

d. Pengukuran risiko dalam prosedur pelunasan sebagian pembiayaan gadai emas di BJB Syariah KCP Kuningan. Pengukuran risiko dalam prosedur pelunasan sebagian pembiayaan gadai emas, ada saat keberadaan nasabah memenuhi persyaratan data yang dibutuhkan, konsekuensi dari adanya pelunasan sebagian yang membutuhkan waktu lagi untuk dapat melakukan seluruh kewajibannya (risiko waktu), penaksiran ulang pada kondisi taksiran saat di waktu yang berbeda. Dari semua risiko yang ada dalam pelunasan sebagian memang tidak terdapat risiko yang berarti yang terjadi. Sehingga pengukuran risiko ini masih dapat dikendalikan oleh pihak yang bersangkutan antara pihak bank dan pihak nasabah.

e. Pengkuran risiko dalam prosedur perpanjangan/adendum pembiayaan gadai emas di BJB Syariah KCP Kuningan tidak ada risiko yang tidak diharapkan dalam perpanjangan/adendum pembiayaan gadai emas, yang ada adalah risiko yang diharapkan bank yaitu pendapatan bank bertambah. Sehingga pengukuran risiko di sini, cukup memberikan keuntungan pada nasabah dan bank, karena bank dapat meningkatnya pendapatan dan bagi nasabah dapat mendapatkan pengajuan kembali pembiayaan gadai emas tersebut dengan perpanjangan/adendum pembiayaan gadai emas.

f. Pengukuran risiko dalam prosedur SP 1 s/d SP 2 atau setara 3 pada pembiayaan gadai emas di BJB Syariah KCP Kuningan. Risiko yang tidak diharapkan terjadi di dalam prosedur SP 1 s/d SP 2 atau setara 3 pada pembiayaan gadai emas di BJB Syariah KCP Kuningan yaitu "dalam maintenance sulit menghubungi nasabah untuk memberitahukan kesepakatan atau ujroh yang sudah jatuh tempo". 43 Pengukuran risiko pada prosedur ini termasuk masalah komunikasi, dimana mengkomunikasikan Surat Peringatan (SP) dari bank ke pihak nasabah yang bersangkutan. Hal ini bagi bank tetap masih bisa ditangani ketika masih tidak ada tanggapan dari nasabah yang bersangkutan maka prosedur akan berlanjut ke Surat Peringatan 2 atau setara 3 secara tertulis dan tindakan tidak tertulisnya yaitu menghubungi langsung nasabah dengan menelpon ke nomor kontak yang bisa dihubunginya yang terdapat di data nasabah di bank dan mengunjungi langsung rumah nasabah. Ketika tindakan

${ }^{43}$ Hasil wawancara dengan Pak Dimas Priangga Nugraha, Karyawan Bank BJB Syariah tanggal 16 Oktober 2015 
sebelumnya tidak ada respon atau pilihan sudah dipilih oleh nasabah, maka akan berlanjut sesuai pada ketentuan. Namun, ketika ketentuan untuk dilelang pada keberadaan barang gadai, maka akan dilakukan lelang pada barang gadai tersebut.

g. Pengukuran risiko dalam prosedur lelang barang gadai pada pembiayaan gadai emasdi BJB Syariah KCP Kuningan. Pengukuran risiko yang diharapkan bank dan nasabah pada prosedur lelang pada hakikatnya tidak menginginkan terjadinya lelang, tetapi risiko yang tidak diharapkan pada lelang harus terjadinya prosedur lelang itu sendiri. Karena bagi pihak bank, risiko yang harus dihadapi dalam kegiatan lelang yaitu bank mengadakan acara lelang, jika tidak maka tidak ada tindak lanjut dari adanya barang gadai yang berada di bank dan kewajiban nasabah tidak bisa terlunasi atas pengembalian pembiayaan gadai. Bagi pihak nasabah, pengukuran risiko dalam prosedur lelang, nasabah tidak bisa memiliki kembali barang gadai miliknya. Karena kegiatan lelang dilakukan ketika telah melewati batas waktu yang telah ditentukan sebelumnya.

h. Pengukuran risiko dalam prosedur kuasa lelang barang gadai pada pembiayaan gadai emas di BJB Syariah KCP Kuningan. Pengukuran risiko dalam prosedur kuasa lelang yang berada di pihak bank memiliki konsekuensi adanya kuasa akan melakukan lelang pada barang gadai, yang sebelumnya milik nasabah. Karena kuasa lelang menandakan adanya hak preogratif bagi pihak bank atas barang gadai yang tidak di ambil oleh nasabah.

i. Pengukuran risiko dalam prosedur penjualan barang gadai pada pembiayaan gadai emas di BJB Syariah KCP Kuningan. Pengukuran risiko yang ada dalam prosedur penjualan barang gadai ketika menghadapi perubahan harga jual barang emas perhiasan/logam mulia yang dijadikan sebagai barang gadai oleh nasabah. Risiko yang dihadapi memang tidak begitu signifikan karena memang pada penentuan taksiran sebelumnya atas pencairan barang gadai memiliki persentase tersendiri bagi jenis barang gadai yang berbeda. Dimana emas perhiasan memiliki persentase pencairan sebesar $80 \%$ dan emas logam mulia sebesar 90\%. Sehingga risiko kerugian dalam menghadapi perubahan emas yang ada tidak mempengaruhi begitu besar pada hasil yang akan dipeoleh, walaupun tetap akan berubah harga emas di pasar pada saat itu tetapi jika terjual emas tersebut tetap akan dapat sedikit mengcover kewajiban nasabah yang harus dilunasi.

j. Pengukuran risiko dalam prosedur pelunasan/penutupan pada sistem pembiayaan gadai emas di BJB Syariah KCP Kuningan. Besar kecilnya risiko yang ada dalam prosedur pelunasan/penutupan pada sistem pembiayaan gadai emas, berada pada saat setelah hasil penjualan yang digunakan untuk 
menyelesaikan kewajiban nasabah yang harus di lunasi dan dapat menutup sistem pembiayaan gadai emas yang bersangkutan. Risiko yang dihadapi jika setelah adanya hasil penjualan tetap tidak bisa melunasi kewajiban atas pengembalian pembiayaan gadai emas, maka akan tetap melakukan pelunasan dengan menarik dana dari nasabah tersebut dan jikapun tidak tersedia dananya dalam tabungan nasabah maka akan dilakukan penagihan langsung ke rumahnya dengan menghubungi nasabah tersebut atau kerabatnya.

Secara garis besar, kegiatan menanggapi risiko merupakan kegiatan sebagai berikut: ${ }^{44}$

1) Memahami tiga karakter dasar risiko, yaitu:

a) Dihindari atau dihilangkan, merupakan risiko yang memilki kemungkinan merugikan dan sesuatu yang tidak sesuai dengan tujuan usaha. Kegiatan dalam hal ini seperti menyesuaikan jangka waktu, sindikasi dan investigasi tuntas.

b) Ditransfer atau dialihkan, merupakan risiko yang dapat dialihkan atau ditransfer ke pihak ketiga, seperti bentuk kerugian yang mungkin timbul karena terindikasi ke usaha bank yang unik. Contohnya, konsentrasi kredit yang melampui rencana bank, kredit macet, kecurangan, kelalaian/ keterbatasan manajemen, atau kegagalan

\footnotetext{
${ }^{44}$ Robert Tampubolon, Manajemen Risiko Pendekatan Kualitatif untuk Bank Komersial....9697
}

sistem. Sepanjang memungkinkan dapat dialihkan pada asuransi atau menjualnya pada pihak ketiga.

c) Dikelola, merupakan tindakan yang dapat ditangani oleh sumber daya yang dimiliki bank.

2) Menetapkan tujuan atau hasil atas evaluasi yang sudah diukur

3) Menetapkan pilihan untuk mengurangi kendala dan meningkatkan kesempatan, serta pendekatan dan ketepatan alat yang digunakan

4) Mengurangi kendala dan meningkatkan kesempatan dengan memilih kegiatan yang efektif dan tepat

5) Melakukan pengkajian pada tahap selanjutnya

6) Pengawasan dan pengendalian

\section{Penutup}

Prosedur pembiayaan gadai emas di BJB Syariah KCP Kuningan, yaitu secara garis besar sebenarnya ada 10 prosedur pembiayaan gadai emas yang memiliki aturan tertentu didalamnya yang meliputi: 1) prosedur permohonan pembiayaan gadai emas, prosedur penaksiran barang gadai, prosedur pelunasan penuh, prosedur pelunasan sebagian, prosedur perpanjangan, prosedur SP 1 s/d SP 2 atau setara 3, lelang, kuasa lelang, penjualan, dan pelunasan/penutupan pada system, 2) Risiko-risiko dalam prosedur pembiayaan gadai emas di BJB Syariah KCP Kuningan. Dilihat dari jenis-jenis risiko secara umum dalam prosedur pembiayaan gadai emas terdapat risiko spekulatif, risiko murni, risiko dinamis, risiko khusus, dan risiko fundamental. Jika dilihat dari beberapa risiko yang dimiiliki perbankan atas risiko yang ada pada 
prosedur pembiayaan gadai emas terdapat risiko kredit, risiko pasar, risiko operasional, 3)Manajemen risiko dalam prosedur pembiayaan gadai emas di BJB Syariah KCP Kuningan dilakukan dengan beberapa kegiatan pada setiap prosedur yang ada pada pembiayaan gadai emas, yang meliputi identifikasi, pengukuran, pemetaan, model pengelolaannya dengan sistem pengendalian internal.

Setelah memperhatikan beberapa hal yang berkaitan dengan permasalahan serta hasil penelitian, yaitu diperlukan adanya kesesuaian data yang konsisten pada data yang dimiliki bank sebagai sumber data primer. Perbedaan penyampaian data dan penyajian data dapat memberikan informasi yang tidak tersampaikan dengan baik. Baik data dalam bentuk tulisan maupun data yang tidak tertulis, yang dibutuhkan dalam suatu penelitian untuk dapat tersampaikan hingga pada hasil penelitian yang bersangkutan terutama data mengenai pembiayaan gadai emas di BJB Syariah, sehingga dapat memberikan informasi yang sebenarnya kepada masyarakat.

Manajemen risiko dalam setiap prosedur pembiayaan gadai emas di BJB Syariah KCP Kuningan sudah baik dan harus tetap bisa ditingkatkan lagi dalam menghadapi segala kemungkinan yang tidak bisa diketahui dengan pasti dan jelas. walaupun ada risiko teknis bisa ditangani dengan mudah pada setiap prosedurnya, tetap harus bisa menjaga terlaksananya setiap prosedur dengan baik.

\section{Daftar Pustaka}

Al-Qur'anul Karim Departemen Agama Republik Indonesia, 2003.
Al-Qur,an dan Terjemahannya juz 1- juz 30. Jakarta: Yayasan Penerjemah Depag.

Agustini, Erlina dan Darul Ulum. 25 Januari 2010. Manajemen Risiko Bank Syariah. 25 Januari. File://mnt/sdcard/Download/manaj emen-risiko-perbankansyariah.webarchivexml.

Akramunnas, Analisis Permasalahan, Ali, Masyhud. 2006. Manajemen Risiko Strategi Perbankan dan Dunia Usaha Menghadapi Tantangan Globalisasi Bisnis. Jakarta: PT Raja Grafika Persada.

Alhusaini, Al-Imam Taqiyuddin Abubakar. 2011. Kifayatul Akhyar. Surabaya: PT.Bina Ilmu.

Al-Jaziry, Abdurrahman. t.t. al-Fiqh ala Madzahib al-Arba'ah. Beirut:Darul-Qalam.

Al-Juhaili, Wahbah. 1989. AlFiqh Al Islami wa'Adillatun, juz IV. Damasyik, Dar Al-Fikr.

Al-Mundziri. 2003. Ringkasan Sahih Muslim. Bandung: Jabal.

Asy-Syarbini, Muhammad. Mugni AlMuhtaj, juz II

Aziz, Abdul. 2010. Manajemen Investasi Syariah, Bandung: Alfabeta.

Bakker, Anton dan Haris, Ahmad Zubair. 1994. Metodologi Penelitian Filsafat. Yogyakarta: Kanisius.

Binah. 2005. Jaminan Gadai Dalam Pandangan Ekonomi Syari'ah ( Studi Kasus Tentang Perjanjian Gadai Pada Perum Pegadaian Cabang Cirebon".Cirebon: IAIN Cirebon.

Burhan, dan Hasbi Lawrens.t.t.Kamus Ilmiah Populer .Jombang: Lintas Media.

Dian RP. t.t. Analisis Manajemen Risiko Pembiayaan dan 
Pengaruhnya Terhadap Laba (Studi Kasus PT Bank x), skripsi pada Departemen Manajemen, Fakultas Ekonomi dan Manajemen, Institut Pertanian Bogor.

Djojosoedarso, Soeisno. 1999. PrinsipPrinsip Manajemen Risiko Dan Asuransi. Jakarta: Salemba Empat.

Dokumen/arsif KCP BJB Syariah Kuningan

Darmawi, Herman. 2006, Manajemen Risiko. Jakarta: Bumi Aksara.

Dewan Syariah Nasional MUI. 2014. Himpunan Fatwa Keuangan Syariah. Jakarta: Erlangga.

Djunaedi, Endang. 2013. Manajemen Bisnis Sebuah Pengantar. Yogyakarta: Deepublish.

Emrald Alamsyah,Ichsan. 2016.BRI Syariah bentuk MOU dengan Parmusi. Jakarta: Republika.

Emrald Alamsyah,Ichsan.2016. Bank Syariah Mampu Jaga NPF. Jakarta: Republika.

Emzir, 2012, Analisis Data, Jakarta: Rajawali Pers.

Ervina, Zeni, Rachmi Sulistyarini dan Yenni Eta Widyanti." Penerapan Peraturan Bank Indonesia No,13/23/Pbi/2011 Tentang Manajemen Risiko Bagi Bni Syariah Pada Produk Gadai Emas "(studi kasus di BNI Syariah cabang Malang).

Hadi,Saiful.2013.Analisis Praktek Bagi Hasilantara Juragan dan Nelayan Perspektif Hukum Bisnis Islam ( studi kasusmasyarakat nelayan PPI Karongsong Indramayu ) Cirebon: IAIN Cirebon.

Herujito,Yayat M. 2001. Dasar-Dasar Manajemen. Jakarta: PT Grasindo.

Hidayat,Wawan K. 2014.Pengenalan Organisasi BJBS (Bandung:
Materi Rundown Acara Pengenalan Produk Dan Jasa Perbankan Syariah)

Ismail. 2011. Perbankan Syariah. Jakarta: Kencana.

Karim, Adiwarman A. 2004. Bank Islam Analisis Fiqih dan Keuangan. Jakarta: PT. Raja Grafindo Persada.

Kartiwa, Budi. 2014. Pengenalan Produk Dan Jasa Perbankan Syariah, BATCH III. Bandung: BJBS, 1 Januari.

Kasidi. 2010. Manajemen Risiko. Bogor: Ghalia Indonesia.

Kasmir. 2003. Manajemen Perbankan. Jakarta: Raja Grafindo Persada.

Katsoff O, Lois. 1992. Pengantar Filsafat, terj.Suyono Sumargono. Yogyakarta: Tiara Wacana.

Khan, Tariqullah dan Habib Ahmad. 2008.Manajemen Risiko Lemaga Keuangan Syariah Jakarta: Bumi Aksar.

Kholifah, Nadhifatul. Topowijoyo dan Devi Farah Azizah. 2013. Analisis Sistem Dan Prosedur Gadai Emas Syariah (StudiPada PT. Bank Mega Syariah Dan PT. Bank BNI Syariah Kantor Cabang Malang).

Komarudin. 2007. Pemanfaatan Jaminan Dalam Kontrak Gadai Menurut Tinjauan Hukum Islam (Studi Kasus Pelaksanaan Gadai Sawah di Desa Sliyeg Kec.Sliyeg Kab. Cirebon). Cirebon: IAIN Cirebon.

Maimunah.2008. Analisa Pelaksanaan Gadai Syari'ah Dalam Kajian Hukum Islam (Studi Kasus Pada Perum Pegadaian Syari'ah Cabang Cipto).Cirebon: IAIN Cirebon.

Mardalis. 1999. Metode Penelitian Satu Pendekatan Proposal. Jakarta: PT.Bumi Aksara. 
Maulidizen, Ahmad. "Jurnal Gadai Emas Syariah Pada Bri Syariah Cabang Pekanbaru”, file:///mnt/sdcard/Download/jurnal _gadai_emas_syariah.h ml1,webarchivexml.

Burhan. Dan Hasbi Lawrens.t.t.Kamus Ilmiah Populer. Jombang: Lintas Media.

Mudjab Mahali, Ahamad dan Ahmad Rodli Hasbullah,. 2004. "HadisHadis Mutaffaq'Alaih bagian Munakahat dan Mu'amalat. Ed. 1. Cet. 1. No. 935Jakarta: Knencana.

MUI. 2013. Mengenal dan Mewaspadai Penyimpangan Syiah. Jakarta: Nasdasanah.

Munawar, Fansuri. "Ekono Pendidikan di Era Global". Jurnal Pendidikan Agama Islam Ta'lim Vol.10 No.2_2012

Prawirosentono, Suyadi. 2007. Manajemen operasi_analisis dan studi kasus (Jakarta: Bumi Aksara.

Pribawa, Teguh dan Ponco Wahyu. 2014. Pengenalan Produk dana dan Jasa BJBS (Bandung: Materi Rundown Acara Pengenalan Produk Dan Jasa Perbankan Syariah)

Qudamah,Ibn. Mugni Al Muhtaj, juz II.

Rahman, Afzalur. 1996. Doktrin Ekonomi Islam jilid 4. Yogyakarta: PT. Dana Bhakti Wakal.

Rahmad, Basuki. 2011. Hukum Waris. Jakarta: Senayan Abadi Publishing.

Rianto Rustam, Bambang. 2013. Manajemen Risiko Perbankan Syariah di Indonesia. Jakarta: Salemba Empat.

Ristqi P, Anita. Aspek Risiko Produk Gadai Emas Pada Pegadaian Syariah Cabang Cinere, ANITA_RISTOL_P-FSH-1.pdf.
Rivai,Veithzal. Andria Permata Veithzal dan Ferry N. Indroes. 2007. BANK AND FINANCIAL INSTITUTION MANAGEMENT Conventional \& Sharia System. Jakarta: PT Rajagrafindo Persada.

Rivai, Veithzal. Sofyan Basir, Sarwono Sudarto, dan Ariflandy Permata Veithzal. 2012. COMMERCIAL BANK MANAGEMENT MANAJEMEN PERBANKAN dari teori ke praktek. Jakarta: PT Raja Grafindo Persada.

Rohaida, Siti. 2013. Pengaruh Manajemen Risiko Pembiayaan Murabahah dan Kelancaran Pengembalian pembiayaan terhadap Kualitas Aktiva Produktif. Cirebon: IAIN Cirebon. Sabiq, Sayyid. 1987. Fiqhus Sunnah. Beirut: Darul-Kitab al-Arabi.

Sagita, Yulian. 2011. Tinjauan Syariah Tentang Sistem Lelang Di Pegadaian Syariah Cabang Cirebon. Cirebon: IAIN Cirebon.

Saksomo,Wurianto. Teori Penelitian Analisis Isi, 17 April 2013. http://wuriantos.blogspot.co.id/201 3/04/teori-penelitian-analisisisi.html.

Sedarmayanti. 2014. Manajemen Strategi, Bandung: Refika Aditama.

Setiawan. Kamus Besar Bahasa Indonesia.kbbi.web.id/analisis.

Shihab,M. Quraish. 2002. Tafsir AlMisbah pesan, kesan dan keserasian Al-Qur,an. Jakarta: Lentera Hati.

Sholehah, Mar'atus. 2015. "Persepsi Ulama Tentang Praktek Bagi Hasil Pembiayaan Mudharabah di Perbankan Syariah (Study Kasus Ulama Pengasuh Pondok Pesantren Babakan Ciwaringin Cirebon)". Cirebon: IAIN Cirebon 
Sugiyono. 2012. Metodel Penelitian Kuantitatif, Kualitatif, dan $R \& D$. Bandung: Alfabeta.

Sudarsono, Heri. 2003. Bank dan Lembaga Keuangan Syariah. Yogyakarta: Ekonisia.

Suebah. 2008. Prosedur Aqad Gadai Dalam Tinjauan Hukum Islam (Studi Kasus Di Perum Pegadaian Cabang Klayan). Cirebon: IAIN Cirebon.

Surahmad, Winarno. 1994. Pengantar Penelitian Ilmiah. Bandung: Tarshito.

Soemitra, Andri. 2009. Bank \& Lembaga Keuangan Syariah. Jakarta: Kencana.

Syafi'i Antonio, Muhammad. 2001. Bank Syariah dari teori ke praktek. Jakarta: Gema Insani.

Syafei, Rachmat. 2001. Fiqih Muamalah. Bandung: Pustaka Setia.

Tampubolon, $\quad 2004$. Manajemen Risiko Pendekatan Kualitatif untuk Bank Komersial.
Jakarta: PT Elex Media Komputindo.

Tohirin. 2012.Metode Penelitian Kualitatif dalam pendidikan dan bimbingan konseling. Jakarta: PT. Raja Grafindo Persada.

Ulfah, Maria. 2003. Tinjauan Ekonomi Islam terhadap Benda bukan Hak Milik yang Dijadikan Agunan dalam Gadai (studi kasus di Perum Pegadaian Cabang Gebang Cirebon) Cirebon: STAIN CIREBON.

Usman, Rachmadi. 2009. Hukum Jaminan Keperdataan, -Ed. 1. Cet. 2.Jakarta: Sinar Grafika.

Widiyono,Try. 2009. Agunan Kredit dalam Financial Engineering $I$. Bogor:Ghalia Indonesia.

Www.bjbsyriah.co.id/ilustrasipembiayaan-kepemilikan-emas

Zainuddin dan Muhammad Jamhari. 1999. Al-Islam 2 Muamalah dan Akhlaq,(Bandung: Pustaka Setia) 